\title{
THE COMPLEX HYDROTECHNIC STRUCTURE IN BANAT HYDROGRAPHICAL AREA
}

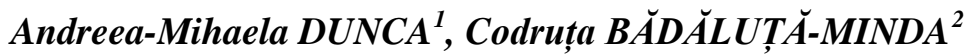

\begin{abstract}
The complex hydrotechnic structure in Banat hydrographical area. Banat hydrographical area benefits of important water resources but also of a complex hydrotechnics planning, represented by a series of permanent and in permanent accumulations, several derivation channels, long segments of rivers dammed and a strong link between the Timiș river and Bega river, which are the main rivers in the area, given by the two channels transferring water from one river to the other and vice-versa. In this paper, after describing the characteristics of Banat hydrographical area and management works of waters from this hydrographical system, we realize an analysis regarding the major water management schemes. In the end of the paper, there are presented the conclusions referring to the management and the utility of water management works from the Banat hydrographical area.
\end{abstract}

Keywords: Banat hydrographical area, water resources, hydrotechnic planning, permanent accumulations, planning schemes of waters.

\section{INTRODUCTION}

Banat hydrographical area is situated in the wastern part and southwestern part of Romania, limited to the north of Mureș river, to the south of Danube river, to the west of the border between Romania and Serbia and to the east bordering Mureș hydrographical basin.

This hydrographical area covers a surface of $18.320 \mathrm{~km}^{2}$ (almost 7,7 \% from the surface of Romania) and includes several river hydrographical basins namely: Aranca, Bega Veche, Bega, Timiș, Bârzava, Moravița, Caraș, Nera, Cerna and other smaller tributaries of the Danube river.

Banat River Basin Administration it's the subsidiary with legal entity of the National Administration „Romanian Waters”, which manages most of the water resources of the two administrative units in which operates namely: System of Water Management Timiș, located in Timișoara and System of Water Management Caraș-Severin, located in Reșița.

The infrastructure of Banat River Basin Administration includes: 4 hydrotechnical knots, $35 \mathrm{~km}$ canals for aduction, $1037 \mathrm{~km}$ regularised rivers, 66 $\mathrm{km}$ enforced river banks, 43 accumulation lakes, $1085 \mathrm{~km}$ dams to protect against flood damages to the houses and to the agricultural lands and $44 \mathrm{~km}$ channels.

1 West University of Timișoara, Faculty of Chemestry, Biology, Geography, Departament of Geography, V. Pârvan Blvd., no. 4, 300223, Timișoara, Romania, email: andreea.dunca@e-uvt.ro

2 Politehnica University, Hydrotechnical Department, G. Enescu Str., no. 1A, 300022, Timişoara, Romania, e-mail: badaluta_minda@yahoo.com 
The hydrometric and hydrogeologic network of the Banat hydrographical area includes: 5 hydrological stations (Timișoara, Lugoj, Reșița, Oravița and Băile Herculane), 80 hydrometrical stations, 8 hydrometrical stations in Sebeş hydrographical experimental and representative basin, 2 lake evaporimetric stations, 73 automatic stations for monitoring level of the rivers, temperature and precipitations, 22 sections gauging the uses of water, 65 satellite sections, 84 hydrological and hydrogeological springs, 598 drillings and 49 automatic stations for drillings (www.rowater.ro/dabanat).

The Management Plan of the Hydrographic Space of Banat 2016-2021 drafted by Banat River Basin Administration and approved by the Government în december 2016 is the planning instrument in water domain in this area river water level. It is based on the monitorization of measures implementation of the National Plan of Management approved in 2011 and includes a Program of Measures to be taken in the water domain of the Director Scheme of Planning and Management of the Banat hydrographical area until 2021, in order for all environment objectives to be achieved.

This plan of Banat hydrographical area includes: the presentation of categories and surface water bodies $(6706,58 \mathrm{~km}$ natural, heavily modified and artificial rivers bed, of which: 4451,79 km permanent rivers and 2.254,79 km inpermanent rivers, plus Danube river with length of $145 \mathrm{~km}$ in the section of bordering the hydrographical area and 9 reservoirs with an area greater than 0,5 $\mathrm{km}^{2}$ ), identification of significant pressures and the significant potential, represented by point and diffuse pollution sources (urban, agricultural, industrial), morphological pressures (dams, reservoirs etc.) and other anthropogenic pressures (aquaculture activities, accidental sources of pollution) (The Management Plan of the Hydrographic Space of Banat 2016-2021).

\section{THE CHARACTERISTICS OF BANAT HYDROGRAPHICAL AREA}

Banat hydrographical area covers the territory of 5 counties: Timiş (integral), Caraș-Severin (integral), Arad (partially), Gorj (partially) and Mehedinți (partially) and is characterized by the variety of relief, thanks to the presence of all forms of the relief that dropped in altitude from southeast to northwest (fig. 1).

From a climatic perspective, Banat hydrographical area falls in the transition temperate continental climate with mediterranean influences, the result of overlapping atlantic air circulation with invasions of mediterranean air. This climate generates a moderate character of the thermal regime, with periods of heating in winter and also of the pluviometric regime, the annual average of precipitations amount ranging from 600-1400 mm/year.

As a result of the diversity of landforms from Banat hydrographical area, which determines a storyng of climatic parameters and as a result of exposure to this hydrographical space in the path of advection of western, northern and southwestern air masses, high waters and floods throughout the year are produced. 


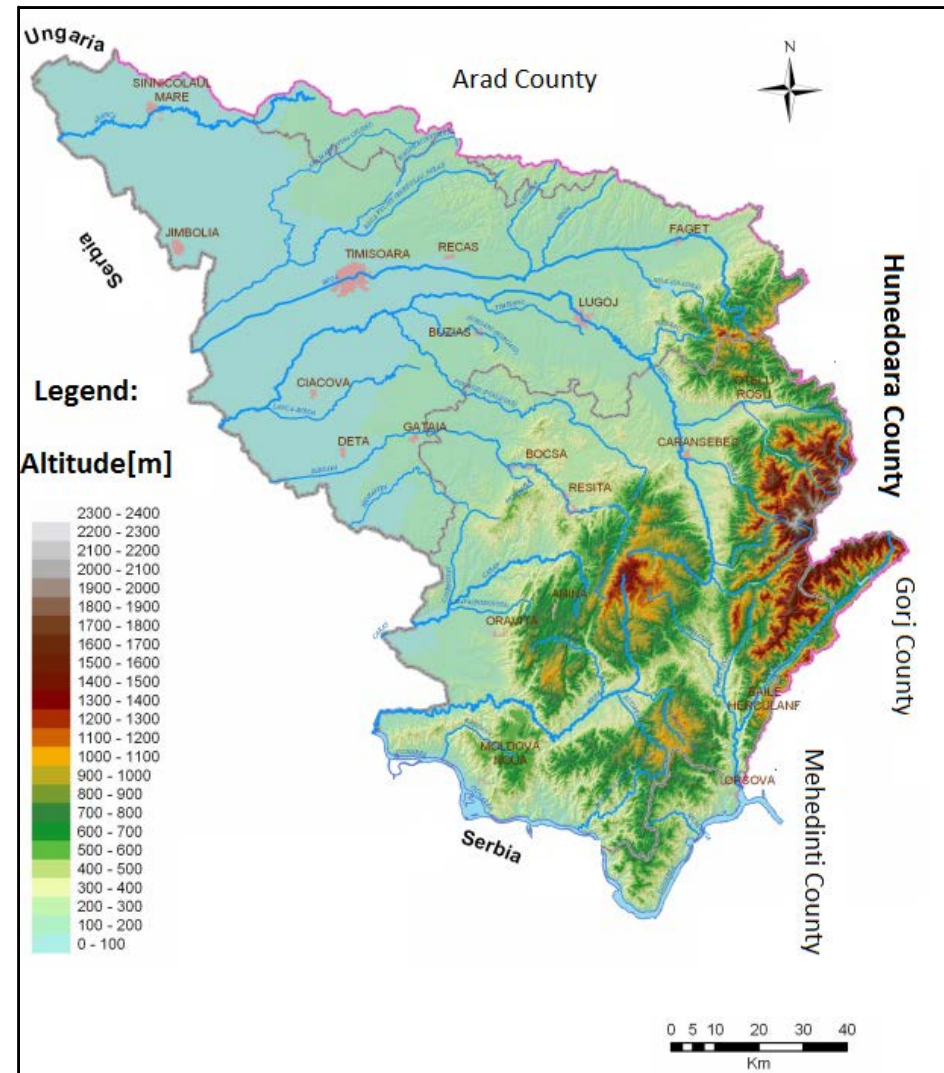

Fig. 1. Hypsometric map of the Banat hydrographical area (Source: A.B.A. Banat)

The highest frequency of flooding occurs in spring when on the saturated soils with water sudden melting of snow is produced, also falling the downpours or combination of the two factors, which leads to the formation of floods with high intensity, but also in the summer when there are flash floods due to downpours fallen on small or extensive areas (Arba, 2010).

From geological point of view in Banat hydrographical area the predominant type of rocks are the siliceous rocks. The calcareous rocks are particularly found into strips and organic rocks which occupy small areas. The mountain formations belong to indigenous crystalline and Getic Canvas, and at the plain are found: sands, clays, red clays, loess, limestones, sandstones, marls, sandy marls and gravels (The Management Plan of the Hydrographic Space of Banat 2016-2021).

The surface water resources of the hydrographical space managed by A.B.A. Banat includes: water resources of the 6 hydrographical basins of rivers: Aranca, Bega, Timiş, Caraş, Nera, Cerna and water resources of Danube river. The total length of hydrographical network related to the hydrographical space managed by A.B.A. Banat is $6705 \mathrm{~km}$ long and its territory, water resources are monitored through 81 hydrometric stations. 
The largest and most important hydrographical basins from Banat hydrographical area are: the hydrographical basin of Timiș river $\left(5673 \mathrm{~km}^{2}\right)$ and the hydrographical basin of Bega river $\left(2362 \mathrm{~km}^{2}\right)$ which together represent approx. $43 \%$ of this hydrographical space which have a much special situation because of human intervention of the natural drainage systems on the two rivers (www.rowater.ro/dabanat).

The Banat hydrographical area, especially its low surface, has been affected by frequent occurance of large floods, which have caused many negative effects among which are: flooding the vast areas of land, registration of numerous property damage, evacuation of the population and even loss of human lives.

In the past centuries, before regularization of rivers from the Banat hydrographical area, rivers floods were very common and fed the marshes, which were chained in the flow direction of watercourses from this basin. The extent of those marshes was so imposing that the acclaimed Francesco Griselini italian historiographer mentioned about them in "Istoria Banatului Timișan” that exceeded the famous pontic swamps from Italy region (Griselini, 1779).

\section{WATER MANAGEMENT WORKS AND PLANNING SCHEMES OF BANAT HYDROGRAPHICAL AREA}

The issue of flood protection was imposed after 1753, when the oldest floods recorded in historical documents were occured and when the habsburg empire concluded that it was necessary to realise some hydrotehnic constructions for reducing the negative effects which can be produce by floods and flash floods (Cozma et al., 1974).

Solving this problem was made possible by carrying out some damming of rivers in some sections with high risk of floods through construction of permanent and non-permanent storages.

Thanks to hydrological improuvement works began in the eighteenth century, watercourses for the most part were settled and the old mashes and swamps were converted into agricutural land.

From Timişoara hydro-power plant and to the confluence with Tisa river, Bega river bed has a slope very low $(0,18 \%)$, the reason why it was dammed on both sides and was transformed into a waterway (The Management Plan of the Hydrographic Space of Banat 2016-2021).

Once the regularisation of watercourses from Banatului Plain was built between 1759-1761, an interconnection between Timiș and Bega was conducted by Maximilian Fremaut to ensure the necessary water for Timișoara, of water flow useful for navigation on the Bega Channel and prevent possible flood for Timișoara area and downstream from it (fig. 2).

The Timiș-Bega Interconnection is a double connection consisting of two channels connecting the Timiș river and Bega river meaning the Coștei-Chizătău supply Channel, realized for supply the natural flow of Bega river and Topolovăț 
discharge channel, realized for transferring the flood peaks from Bega river to Timiș river (Arba, 2016).

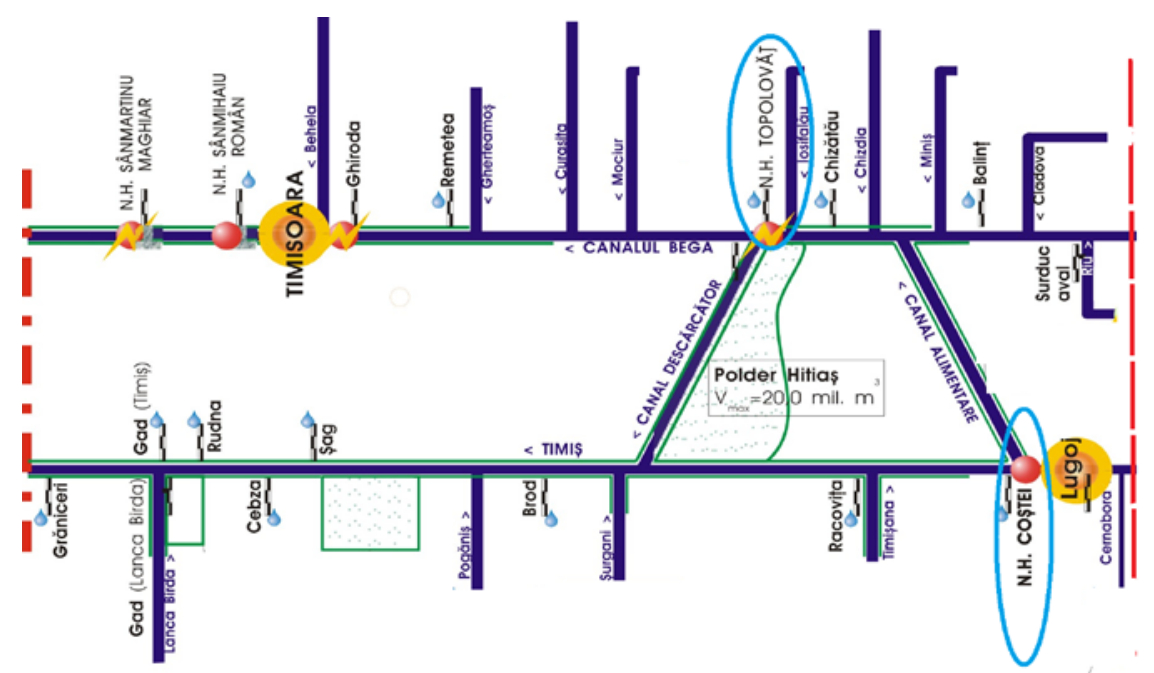

Fig. 2. The Timiş-Bega Interconnection - sinoptic scheme (Source: A.B.A. Banat)

The damming works of the main rivers from Banat hydrographical area were realised with the purpose of flood protection, on their middle and lower courses, in the lower subsidence areas, with large excess moisture and where the slope is very low and rich runoff, so with a very high probability of floods (Arba, 2016).

The complex scheme of the Bega Channel with the purpose to combat possible floods which can be produced by Bega river during the high water periods and the excess of humidity from the Bega hydrographical basin, for navigation and assuring the necessary of drinkable and industrial water for rural and urban localities and for inhabitants.

Hydrotechnical works from this area are represented by: operations for channeling and regularisation of the Bega watercourse on the sector of confluence of the silling channel Timiș-Bega-Serbian border, water derivation works from the Timiș river into the Bega Channel and vice-versa through the means of the TimişBega interconnection, damming works on the rivers, hydrotechnical knots for diversion (Coștei on Timiș river and Topolovăț on Bega river), separation hydrotechnical knots (Hydro-power plant - H.P.P. Timișoara) and separation hydrotechnical knots for navigation (Sânmihaiu Român and Sânmartinu Maghiar) and the hydrological improvnement works made for the purpose of removal under flooding the land surface of approximately 226.000 ha (www.rowater.ro/dabanat).

The complex scheme of the Upper Bârzava hydrographical basin has the purpose of assuring the provision of drinking and industrial water of the Reșița municipality from the Bârzava river and production of hydroelectric energy.

Hydrotechnical works from the Upper Bârzava hydrographical basin are represented by: accumulation lakes realised on the Bârzava river (Gozna, Văliug și 
Secu), which allow the need for water used in Reșiţa and contribute to valorification of hydroenergetic potential of the basin and on Timiș river (Trei Ape), which suppliment the river flows on the Bârzava river, the derivations, the aductions, the channels and the installations for production of electric energy from the region (www.rowater.ro/dabanat).

Most of the flood defense works from the Banat hydrographical area were realized within hydrographical basin of Timiș and Bega rivers.

In Banat hydrographical area there are 43 storage lakes, of which 27 are non-permanent storage lakes. In this hydrographical basin 9 accumulations with the surface greater than $0,5 \mathrm{~km}^{2}$ have been identified. These accumulations were built with multiple purposes: against flood defense, drinking and industrial water supply, energy, irrigations and fish farming etc. (fig. 3)

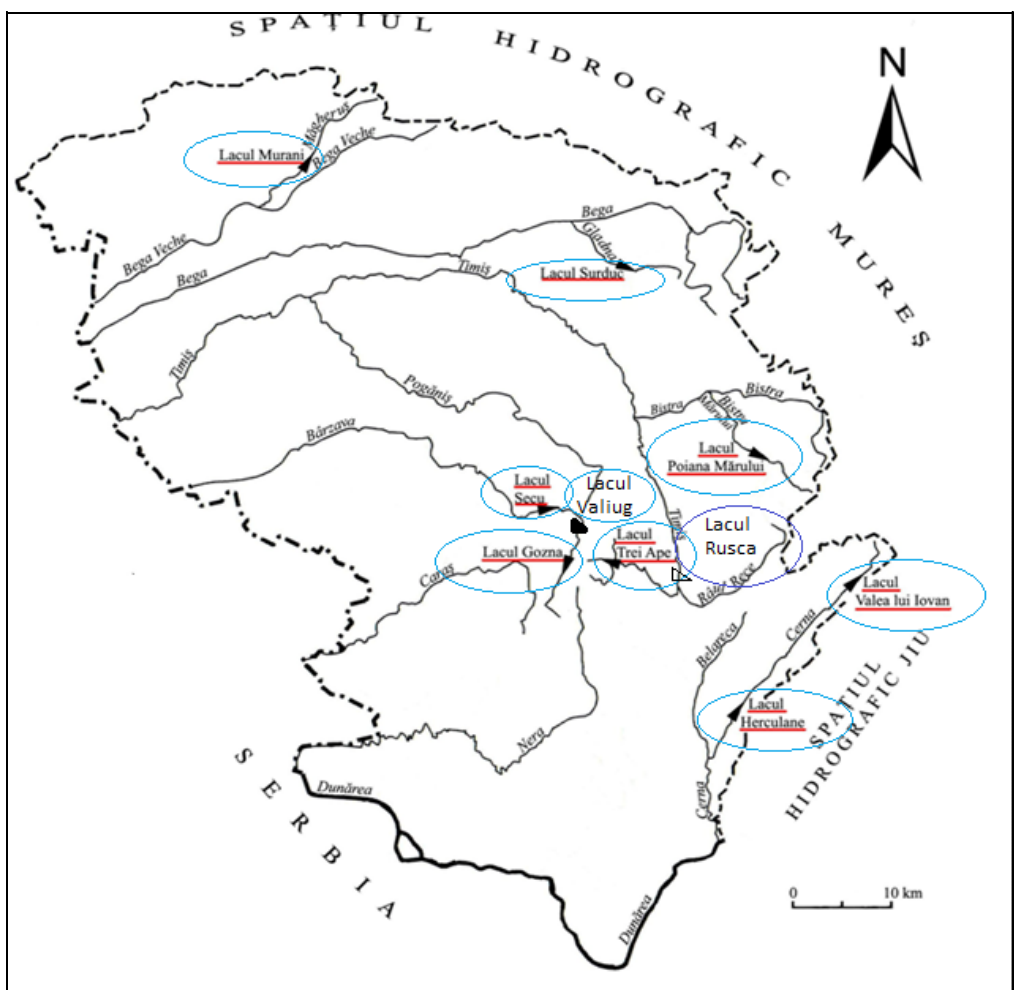

Fig. 3. The most important storage lakes from the Banat hydrographical area

(Source: A.B.A. Banat)

The most important accumulations from this hydrographical space are:

- in Bega hydrographical basin: Murani accumulation and Surduc accumulation;

- in Timiș hydrographical basin: Trei Ape accumulation, Poiana Mărului accumulation and Rusca accumulation; 
- in Bârzava hydrographical basin: Secu accumulation and Gozna accumulation;

- in Cerna hydrographical basin: Valea lui Iovan accumulation and Herculane accumulation.

Flash floods formed under natural conditions on the upper river of the upper course of Bârzava river are heavily modified by the accumulations Gozna și Secu, such as downstream the Secu accumulation, floods recorded over the future are the result of overlapping the flow defluente remaining pool of storage (fig. 4) (Bădăluță-Minda, 2016).

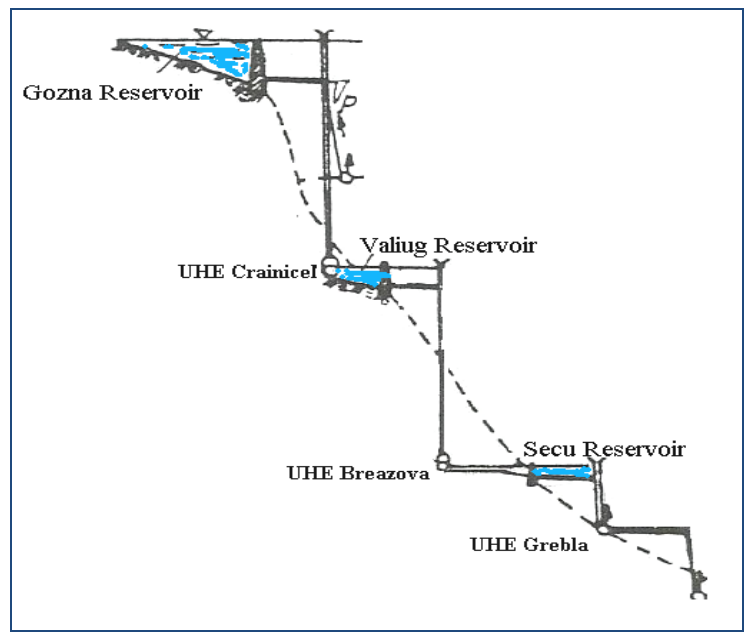

Fig. 4. The planning scheme of Upper Bârzava river

Bârzava river has the most complex level of panning from Caraș-Severin county, has a length of $99 \mathrm{~km}$, average slope $11 \mathrm{~m} / \mathrm{km}$ and Secu accumulations built on this river, from $15 \mathrm{mil} . \mathrm{m}^{3}$ approximately half $\left(7,21 \mathrm{mil} . \mathrm{m}^{3}\right)$ is the volume of mitigate flood waves .

On Secu - Câlnic section, Bârzava river is regulated so as to lead flood with guarantee $1 \%$. The regularization consists of bottom sills, river banks enforced in the form of pears and walls, damming of rivers downstream.

On the left bank of Bârzava river, downstream of the confluence with the Fizeș brook, near the Gherteniş locality is located the Gherteniş non-permanent accumulation with the aime to mitigate floods on Bârzava river.

\section{CONCLUSIONS}

In order to combat the destructive effects of floods, the lower reach of Bega river was arranged and corrected, which in the last centuries affected large land areas. The 20th century brings extreme hydrological events; the most important floods are of the years 1912, 1966, 1999, followed by those produced in 
the 21st century. On this line was built the waterway Bega, which takes over water from Bega river during the low and average waters, and leads it toward Serbia, respectively the bypass channel with Timiș river.

The embankment works and river training existing in the Banat hydrographical area, present a different character compared to most similar works from the country, namely the fact as the main rivers, components of the space cross the state border, situation imposing a series of common rules regarding the way resolve the problems of flood control, generated by these watercourses.

The water management works are operated efficiently, along the purpose of the defense against floods, they are used for other aims, such as: drinking and industrial water supply, energy, regulated flow of watercourses

\section{REFERENCES}

1. Arba, Andreea, Mihaela, (2010) - History of floods occurred in Banat, Review of Historical Geography and Toponomastics (RHGT), volumul V, nr. 9-10, Editura Universităţii de Vest, Timişoara, pp. 45-52;

2. Arba, Andreea, Mihaela, (2016) - Resursele de apă din sistemul hidrografic Timişs-Bega: geneyă, regim hidrologic și riscuri hidrice, Editura Universităţii de Vest, Timişoara;

3. Bădăluță-Minda, Codruța, (2016) - The Study of using Wind Energy to Hydropower Designs with Pump, Hydrology Current Research, vol.7, Issue 1

4. Cojocaru, M., (2005), Tradiție și modernitate, Hidroconstructia, București;

5. Cozma, M., Oprea, V., Văcaru, P., (1974) - Pământuri renăscute, sisteme de desecări în Județul Timiş, edited by General Directorate of Agriculture, Food Industry and Wtaers from Timiș County based on the printed program approved by Committee Office of P.C.R., Timiș County, 84 p.;

6. Crețu, Gh., Bădăluță-Minda, Codruța, (2007) - Model for floods simulation and floods occurred due to the breaching of the longitudinal defense hydro technical works”, International Conference Disaster and pollution monitoring, Iași, Romania, 2007, pp. 47-54;

7. Griselini, Fr., (1779) - Versuch einer politishen und natürlichen Geschichte des Temeswarer Banats in briefen an standespersonen un gelehrte, Wienn, tradusă de Bolocan, N., (1926) - Istoria Banatului Timișan, Editura Tipografiile Române Unite, Bucureşti, pp. 108-143;

8. Griselini, Fr., (1779) - Versuch einer politishen und natürlichen Geschichte des Temeswarer Banats in briefen an standespersonen un gelehrte, Wienn, tradusă de Feneşan, C., (1984) - Încercare de istorie politică şi naturală a Banatului Timişoarei, Editura Facla, Timişoara, 336 p.;

9. *** (2012), Prevention, Protection and Flood Mitigation Plan in Banat hydrographical basin, Banat River Basin Administration (A.B.A.B.), Timișoara, National Administration „Romanian Waters”;

10. *** (2016), Planul de Management al Spațiului Hidrografic Banat 2016-2021, Banat River Basin Administration (A.B.A.B.), Timişoara, National Administration „Romanian Waters”;

11. http://www.rowater.ro/dabanat/default.aspx 